\title{
Analisis dan Strategi Peningkatan Pendapatan Asli Daerah (PAD) di Kabupaten Gunungkidul
}

\author{
Evi Nilawati \\ Ilmu Administrasi Negara, Universitas Gunung Kidul, Indonesia \\ Korespondensi penulis: alfitra_n@yahoo.co.id
}

\begin{abstract}
Regional Original Revenue (PAD) has a very large contribution to the Regional Budgeting (APBD) to finance the administration and service processes of government affairs and regional development. The present research aims to determine how to improve PAD and build strategy of action plan for increasing it in Gunungkidul Regency. This study used descriptive qualitative method. Informants were taken by purposive sampling. Data collecting techniques are observations, interview with Local Agency Organizations (OPD) which are responsible for PAD generation, and documentations or secondary data, i.e. APBD, PAD, and other relevant data. The results of the study showed that the development of Gunungkidul PAD experienced a significant development as big as 25,97\%. The PAD contribution to regional income or fiscal decentralization rate is $11,73 \%$. The strategy to increase the PAD is built by a formulating action plan for accelerating it. Based on this results, it is suggested that the program to increase competency and commitment of regional tax-retribution managers for each revenue management of local agency, provide a program to increase the PAD and implementation of the action plan to increase it, use information and communication technology for the management of each PAD lines, and optimally stakeholders cooperation building.
\end{abstract}

Keywords: SWOT analysis; Local government strategy; Regional Original Revenue; Gunungkidul Regency.

Abstrak. Pendapatan Asli Daerah (PAD) memberikan kontribusi yang besar terhadap
Anggaran Pendapatan dan Belanja Daerah (APBD) untuk membiayai penyelenggaraan
proses administrasi dan layanan pemerintahan dan pembangunan daerah. Penelitian ini
bertujuan untuk memahami bagaimana mengembangkan PAD serta strategi dan rencana
aksi peningkatan PAD di Kabupaten Gunungkidul. Penelitian ini menggunakan metode
diskriptif kualitatif. Informan ditentukan dengan metode sampel bertujuan. Teknik
pengumpulan data yang digunakan meliputi observasi, wawancara dengan Organisasi
Perangkat Daerah (OPD) sebagai pengelola PAD, dan dokumentasi berupa data sekun-
der, di antaranya adalah APBD, PAD, dan data lain yang relevan. Hasil penelitian
menunjukkan bahwa PAD Kabupaten Gunungkidul mengalami perkembangan signifi-
kan sebesar 25,97\%, sedangkan kontribusi PAD terhadap pendapatan daerah atau
derajad desentralisasi fiskal sebesar $11,73 \%$. Strategi peningkatan PAD ditempuh
dengan penyusunan rencana aksi percepatan peningkatan PAD. Hasil penelitian ini
menyarankan perlunya program peningkatan kompetensi dan komitmen pengelola 
pajak-retribusi daerah pada masing-masing OPD pengelola pendapatan, program peningkatan PAD dan implementasi rencana aksi peningkatan PAD, pemanfaatan teknologi informasi dan komunikasi untuk pengelolaan setiap lini PAD, dan membangun kerjasama antarpihak secara lebih optimal.

Kata kunci: Analisis SWOT; Strategi pemerintah daerah; Pendapatan Asli Daerah; Kabupaten Gunungkidul.

\author{
Article Info: \\ Received: April 20, $2019 \quad$ Accepted: November 7, $2019 \quad$ Available Online: November 11, 2019 \\ DOI: http://dx.doi.org/10.30588/jmp.v9i1.469
}

\title{
LATAR BELAKANG
}

Implementasi otonomi daerah membawa konsekuensi penyerahan kewenangan pemerintah pusat kepada daerah. Era baru pengelolaan keuangan publik untuk mewujudkan akuntabilitas publik melalui desentralisasi keuangan daerah memberikan ruang kepada daerah untuk menggali sumber-sumber pendapatan daerah. Instrumen desentralisasi keuangan daerah adalah Anggaran Pendapatan Belanja Daerah (APBD). Secara administratif Kabupaten Gunungkidul terdiri atas 18 (delapan belas) desa pesisir, 56 (lima puluh enam) desa di lereng bukit, dan 70 (tujuh puluh) desa di dataran serta tersebar di 18 (delapan belas) kecamatan yang dikenal sebagai Kawasan Karst Gunungsewu (Pemerintah Kabupaten Gunungkidul, 2017b). Pemerintah Kabupaten (Pemkab) Gunungkidul menerapkan kebijakan desentralisasi keuangan daerah melalui kebijakan peningkatan Pendapatan Asli Daerah (PAD) dan optimalisasi belanja daerah pada APBD (Pemerintah Kabupaten Gunungkidul, 2017b).

Pendapatan daerah digali berdasarkan potensi dan target yang ditetapkan secara rasional, sedangkan belanja daerah berorientasi pada pencapaian kinerja dan kepentingan publik. Implementasi desentralisasi keuangan daerah dijabarkan pada APBD yang difokuskan pada pencapaian visi pembangunan tahun 2016-2021, yaitu mewujudkan Gunungkidul sebagai daerah tujuan wisata terkemuka dan berbudaya menuju masyarakat yang berdaya saing, maju, mandiri, dan sejahtera tahun 2021 (Pemerintah Kabupaten Gunungkidul, 2017b). Kebijakan desentralisasi keuangan daerah bertujuan meningkatkan kesejahteraan masyarakat berbasis kewilayahan untuk memberikan nilai tambah, baik bagi petani, nelayan, peningkatan industri kreatif, usaha mikro, kecil, dan menengah, serta pariwisata. Untuk merealisasikan tujuan tersebut, Pemkab Gunungkidul mencapainya melalui kebijakan APBD dengan struktur yang terdiri atas pendapatan daerah, belanja daerah, dan pembiayaan daerah.

Kemampuan pemerintah daerah menyelenggarakan tugas pemerintahan dan pembangunan tergantung pada ketiga unsur tersebut. Kemampuan daerah mengoptimalkan potensi dan menggali sumber pendapatan baru sangat menentukan kemandirian keuangan daerah. Peningkatan kemandirian keuangan daerah membutuhkan strategi dan rencana aksi peningkatan PAD yang tepat sesuai kondisi dan karakteristik daerah. Untuk memperkuat derajad kemandirian keuangan daerah diperlukan penelitian analisis dan strategi peningkatan PAD. Penelitian ini bertujuan menganalisis perkembangan PAD dan merumuskan strategi serta rencana aksi peningkatan PAD. 


\section{KAJIAN TEORITIS}

Pendapatan daerah merupakan sejumlah dana yang diterima oleh daerah, baik yang berasal dari hasil usahanya sendiri maupun bantuan dati pemerintah pusat atau sumber lain yang sah. Struktur pendapatan daerah terdiri atas: Pertama, PAD mencakup pajak daerah, retribusi daerah, hasil pengelolaan keuangan daerah yang dipisahkan, dan penerimaan lain yang sah (misalnya hasil penjualan kekayaan daerah yang tidak bisa dipisahkan, jasa giro, pendapatan bunga, keuntungan selisih nilai tukar rupiah dengan uang asing, komisi, potongan, atau pun bentuk-bentuk lain sebagai akibat dari penjualan/pengadaan barang/jasa. Kedua, dana perimbangan yang terdiri atas dana bagi hasil atau DBH (dari pajak, kehutanan, pertambangan umum, perikanan, pertambangan minyak bumi, pertambangan gas bumi, dan pertambangan panas bumi), dana alokasi umum atau DAU yang bersumber dari pendapatan bersih dalam negeri, dan dana alokasi khusus atau DAK. Ketiga, lain-lain pendapatan daerah yang sah, yaitu dana hibah, dana darurat, dana penyesuaian, dana otonomi khusus, dan bantuan dari daerah di atasnya atau daerah lain (Anggara, 2016).

Pengelolaan pendapatan dan belanja daerah mendasarkan pada prinsip bahwa pengeluaran harus didukung dengan kepastian penerimaan dalam jumlah yang cukup. Permasalahan keuangan daerah, antara lain kesenjangan fiskal (fiscal gap) yaitu tingginya kebutuhan fiskal daerah (fiscal need), sedangkan kapasitas fiskal daerah tidak mencukupi. Pengelolaan potensi daerah menentukan PAD atau kemandirian keuangan daerah. Penyesuaian tarif, perbaikan sistem pelayanan, penertiban obyek, dan pemberlakuan sistem denda bagi penunggak merupakan upaya intensifikasi, sedangkan menambah sumber pendapatan baru merupakan upaya ekstensifikasi (Anggara, 2016).

Strategi menutup kesenjangan fiskal pendapatan daerah, yaitu peningkatan pendapatan melalui penjualan jasa publik (charging for public service), perbaikan administrasi penerimaan pendapatan daerah (revenue administration), peningkatan tarif, dan perluasan subyek-obyek pajak. Intensifikasi pemungutan retribusi dan pajak daerah, yaitu: (1) memperluas basis penerimaan potensial secara ekonomi, antara lain mengidentifikasi pembayar pajak baru potensial, jumlah pembayar pajak, memperbaiki basis data obyek pajak, dan menghitung kapasitas penerimaan setiap jenis pungutan; (2) memperkuat proses pemungutan pajak melalui penyusunan Peraturan Daerah (Perda), mengubah tarif, dan peningkatan kapasitas sumber daya manusia; (3) mengawasi melalui pemeriksaan secara mendadak dan periodik, perbaikan sistem pengawasan, penerapan sanksi penunggak pajak dan pihak fiskus, peningkatan pembayaran pajak, dan pelayanan; (4) melakukan efisiensi administrasi dan biaya pemungutan pajak dengan perbaikan prosedur administrasi berupa penyederhanaan administrasi pajak dan efisiensi pungutan; (5) meningkatkan kapasitas penerimaan dalam perencanaan dengan koordinasi instansi terkait. Ekstensifikasi perpajakan dilakukan melalui pemberian kewenangan yang lebih luas kepada daerah. Perubahan sistem perpajakan dilakukan melalui sistem pembagian langsung atau beberapa basis pajak pusat dipungut oleh daerah (Mardiasmo, 2002).

Beberapa hasil penelitian sebelumnya digunakan sebagai referensi dalam penelitian ini. Penelitian Mohamed (2017) menyimpulkan bahwa sumber keuangan daerah belum dilaksanakan secara optimal karena banyaknya tantangan. Penelitian tersebut membahas sistem perpajakan, strategi pengumpulan pendapatan, lemahnya desentralisasi fiskal, dan kurangnya kompetensi petugas pengumpul pendapatan. Kelemahan 
perpajakan ditunjukkan dengan belum adanya basis data pajak. Pemerintah lokal perlu mencari, menggali, dan menciptakan sumber keuangan baru (Mohamed, 2017). Hampir sama dengan penelitian Mohamed (2017), penelitian Cruz et al. (2018) menyimpulkan bahwa keuangan Kota Bongabon tergantung pada pemerintah pusat. Pajak merupakan salah satu potensi sumber pendapatan daerah. Penelitian ini menyarankan agar dilakukan penelitian tentang pajak sebagai input pembuatan kebijakan pajak lokal (Cruz, Cruz, \& Antonio, 2018).

Penelitian Ylvije dan Elez (2012) menyimpulkan bahwa penerimaan pajak sektor pariwisata sangat penting. Penerapan pajak tidak boleh mematikan sektor pariwisata. Penentuan tarif pajak terbaik akan mendorong pengembangan pariwisata dan dana pajak harus digunakan untuk investasi pengembangan pariwisata. Penerapan sistem pajak yang tepat akan mendorong sektor pariwisata dapat berkembang (Ylvije \& Elez, 2012). Penerimaan pendapatan pajak dirasakan belum optimal. Sektor pariwisata perlu ditingkatkan kapasitasnya dan pendapatan sektor ini dapat digunakan untuk membiayai pembangunannya.

Salah satu sumber PAD Kabupaten Gunungkidul adalah pendapatan sektor pariwisata yang meningkat seiring dengan pengembangan pariwisatanya. Namun, upaya pengembangan tersebut masih bertumpu pada pungutan retribusi. FaladeObalade dan Dubey (2014) menyatakan pariwisata berperan penting terhadap pertumbuhan negara berkembang serta memberikan dampak positif terhadap kondisi sosial dan ekonomi negara. Pariwisata sebagai salah satu sektor industri berkontribusi terhadap Pendapatan Domestik Bruto (PDB) negara, kualitas hidup warga, dan penciptaan lapangan kerja. Penelitian Sitompul et al. (2014) menyatakan bahwa pengembangan pariwisata berkaitan dengan faktor amenitas, yaitu ketersediaan hotel dan restoran. Pajak hotel dan restoran berperan penting terhadap PAD Provinsi Banda Aceh. Kontribusi pajak hotel dan restoran masih rendah meskipun sistem pengumpulan pajak cukup efisien dan efektif. Pemerintah daerah seharusnya dapat meningkatkan sistem administrasi perpajakan, kualitas administrator pajak, lebih menekankan upaya intensif daripada ekstensif, dan menerapkan imbalan (reward) dan hukuman (punishment) (Sitompul, Syahnur, \& Ichsan, 2014).

Otieno et al. (2013) menemukan adanya hubungan antara sistem informasi dan efisiensi maupun keefektifan pengumpulan pendapatan pemerintah lokal. Selain itu, ada hubungan positif antara sistem pengendalian internal dan pengumpulan pendapatan. Resistensi terhadap perubahan dapat menghambat implementasi sistem informasi (Otieno et al., 2013). Penelitian oleh Githinji, Mwaniki, Kirwa, dan Mutongwa (2014) menemukan bahwa sistem pemungutan pajak di Kenya relatif buruk dan belum mendapatkan perhatian memadai. Sistem kendali internal terhadap pembayar pajak terbesar adalah sistem informasi manajemen dan infrastruktur teknologi informasi komunikasi pengumpulan pendapatan pemerintah kota (Githinji et al., 2014).

Teknologi dan sistem informasi berpengaruh pada pengumpulan pendapatan (Karimi, Maina, \& Kinyua, 2017). Sebuah penelitian tentang dampak teknologi dan sistem informasi pada pengumpulan pendapatan oleh Pemerintah Daerah Embu di Kenya mengacu teori adopsi teknologi dan merekomendasikan perlunya revisi UndangUndang (UU) dan integrasi sistem informasi manajemen (Karimi et al., 2017). Peningkatan pengumpulan pendapatan pemerintah lokal merupakan kunci untuk memenuhi kewajiban keuangan dalam memberikan layanan publik berkualitas. Banyak 
negara memiliki basis pendapatan memadai, tetapi tingkat pengumpulan pendapatan rendah. Negara gagal mencapai target pengumpulan pendapatan lokal. Temuan penelitian ini bermanfaat bagi pemerintah daerah dalam melakukan perbaikan dan merumuskan kebijakan pengumpulan pendapatan dengan penerapan teknologi dan sistem informasi yang memadai (Karimi et al., 2017). Teknologi informasi memberikan dampak pada administrasi pajak. Teknologi informasi berpengaruh pada produktifitas pajak dan menunjukkan hubungan antara implementasi teknologi informasi pajak dan perencanaan pajak. Teknologi informasi (yang berkaitan dengan pengajuan, pendaftaran dan pembayaran pajak online) mempengaruhi produktifitas pajak, artinya sistem pajak online berpengaruh positif terhadap penerimaan pajak (Olatunji \& Ayodele, 2017).

Pemanfaatan Teknologi Informasi dan Komunikasi (TIK) merupakan salah satu reformasi birokrasi dalam menghadapi Revolusi Industri 4.0 (Amalia, 2018). Hal tersebut berpengaruh pada pelaksanaan tugas dan fungsi yang dilakukan oleh pemerintah (Amalia, 2018). Pemanfaatan TIK pada organisasi pemerintah perlu ditingkatkan dalam mewujudkan tugas dan fungsinya. Demikian pula, pelayanan pajak dan retribusi pemerintah daerah dilaksanakan berbasis e-government. Berdasarkan uraian tersebut, peningkatan PAD dapat diupayakan melalui pemanfaatan teknologi informasi dan komunikasi, sistem informasi, dan pengendalian internal pendapatan pemerintah lokal.

Kemandirian keuangan daerah ditunjukkan melalui kemampuan membiayai sendiri urusan pemerintahan, pembangunan, dan pelayanan masyarakat yang membayar pajak dan retribusi (Putra, 2018). Untuk mewujudkan hal tersebut, berdasarkan hasil penelitian sebelumnya, maka penelitian peningkatan PAD Kabupaten Gunungkidul mencakup pengelolaan potensi wisata, pajak, retribusi wisata, pajak hotel dan restoran, regulasi dan perencanaan, tarif pajak, dan sistem TIK.

Penelitian sebelumnya lebih banyak merumuskan strategi, tetapi belum diimplementasikan secara operasional dengan merumuskan rencana aksi, sehingga hal spesifik yang membedakan penelitian ini dengan penelitian sebelumnya adalah perumusan strategi dan rencana aksi. Arti penting strategi dan rencana aksi peningkatan PAD adalah kebijakan peningkatan $\mathrm{PAD}$ yang lebih terencana, terukur, akuntabel, dan berorientasi pada kinerja (performance). Strategi adalah seni mengintegrasikan antar faktor kunci keberhasilan agar terjadi sinergitas pencapaian tujuan (Lembaga Administrasi Negara, 2008). Penyusunan strategi menggunakan pendekatan formulasi strategi matriks SWOT berdasarkan faktor-faktor internal (strengths, weaknesses) dan faktorfaktor eksternal (opportunities, threats). Setelah strategi ditetapkan, rencana program kegiatan (rencana aksi) dirumuskan untuk mencapai sasaran kinerja yang telah ditetapkan (Lembaga Administrasi Negara, 2008).

\section{METODE PENELITIAN}

Penelitian analisis dan strategi peningkatan PAD di Kabupaten Gunungkidul dilakukan berbasis data pada kurun waktu tahun 2012-2018. Pendekatan diskriptif kualitatif digunakan untuk mendapatkan data yang mendalam (Sugiyono, 2016). Informan dalam penelitian ini diambil dengan metode purposive sampling pada organisasi perangkat daerah (OPD) pengampu pendapatan. Pengumpulan data menggunakan teknik observasi, wawancara terhadap orang-orang kunci OPD pengampu pendapatan, dan dokumentasi berupa data sekunder (meliputi data APBD, data komponen PAD, peraturan terkait PAD, dan data lain yang relevan). Untuk mendapatkan kredibilitas 
data, penelitian ini menerapkan triangulasi berbagai teknik pengumpulan data, yaitu observasi pada saat diskusi Forum Gabungan Perangkat Daerah Pendapatan tahun 2019, data sekunder, dan wawancara pada informan dari Badan Keuangan dan Aset Daerah (BKAD), Badan Perencanaan Pembangunan Daerah (BAPPEDA), dan informan OPD relevan lainnya.

Analisis terhadap data yang terkumpul dilakukan dengan penyajian dan reduksi data untuk mendapatkan pola yang jelas. Penyajian data dilakukan untuk memahami permasalahan yang terjadi, mendapatkan makna atas data, pola hubungan antarbagian dan secara keseluruhan, serta menarik kesimpulan (Sugiyono, 2016). Penelitian ini menggunakan alat analisis SWOT yang terdiri atas kekuatan (strengths), kelemahan (weaknesses), peluang (opportunities), dan ancaman (threaths). SWOT merupakan Teknik Analisis Manajemen (TAM), yaitu sebuah metode ilmiah untuk menilai keadaan lingkungan, baik lingkungan internal maupun eksternal secara komprehensif guna memperoleh informasi faktor kunci keberhasilan dalam mencapai tujuan dan sasaran peningkatan PAD. Indikator faktor internal dan eksternal ditentukan berupa kekuatan, kelemahan, peluang, dan ancaman (Lembaga Administrasi Negara, 2008). Berdasarkan faktor internal dan eksternal tersebut, selanjutnya peneliti melakukan pembobotan dan evaluasi untuk menentukan strategi dan rencana aksi peningkatan PAD.

\section{HASIL DAN PEMBAHASAN}

Penelitian ini berlokasi di Kabupaten Gunungkidul, Yogyakarta dengan memfokuskan pada analisis dan strategi peningkatan PAD. Rentang waktu analisis PAD adalah data tahun 2012-2018. Analisis hasil penelitian disajikan berikut ini.

\section{Diskripsi Pendapatan Asli Daerah (PAD) Kabupaten Gunungkidul}

PAD Kabupaten Gunungkidul adalah pendapatan yang diperoleh dari sumbersumber di dalam daerah meliputi penerimaan pajak daerah, retribusi daerah, hasil pengelolaan kekayaan daerah yang dipisahkan, dan lain-lain PAD yang sah. Pertama, pajak daerah terdiri atas pajak hotel, pajak restoran, pajak hiburan, pajak reklame, pajak penerangan jalan, pajak pengambilan bahan galian golongan $\mathrm{C}$, pajak parkir, pajak air tanah, pajak sarang burung walet, Pajak Bumi dan Bangunan Perdesaan dan Perkotaan (PBB-P2), dan Bea Perolehan Hak Tanah dan Bangunan (BPHTB). Perda Kabupaten Gunungkidul No. 6 Tahun 2017 tentang Pajak Daerah telah menetapkan berbagai jenis pajak daerah sebagai bagian PAD (Pemerintah Kabupaten Gunungkidul, 2017a).

Kedua, retribusi daerah terdiri atas retribusi pelayanan kesehatan, pelayanan persampahan, penggantian biaya akta pencatatan sipil dan Kartu Tanda Penduduk (KTP), pelayanan pengendalian menara telekomunikasi, pemeriksaan kesehatan ternak di Poskeswan, jasa usaha tempat khusus parkir, jasa usaha tempat penginapan/villa, jasa usaha tempat rekreasi dan olahraga, jasa usaha penjualan produksi usaha daerah, ijin mendirikan bangunan, dan ijin trayek. Beberapa Perda tentang retribusi adalah Perda No. 8 Tahun 2011 tentang Retribusi Pelayanan Pasar, Perda No. 5 Tahun 2017 tentang Perubahan kedua atas Perda No. 6 Tahun 2012 tentang Retribusi Tempat Rekreasi dan Olah Raga, dan Perda No. 4 Tahun 2012 tentang Retribusi Pengelolaan Menara Telekomunikasi.

Ketiga, hasil pengelolaan daerah yang dipisahkan terdiri atas penerimaan laba Bank BPD DIY, Perusahaan Daerah (PD) BPR Bank Daerah Gunungkidul (BDG), dan 
Perusahaan Daerah Air Minum (PDAM) Tirta Handayani. Keempat, lain-lain PAD yang sah terdiri atas penerimaan lainnya yang tidak termasuk pada jenis pajak daerah dan retribusi daerah. Pertumbuhan dan sumbangan PAD Kabupaten Gunungkidul disajikan pada Tabel 1 berikut ini.

Tabel 1. Pertumbuhan dan Sumbangan PAD terhadap Pendapatan Daerah

\begin{tabular}{cccccc}
\hline Tahun & $\begin{array}{c}\text { PAD (Rp) / } \\
\text { Pertumbuhan }(\%)\end{array}$ & $\begin{array}{c}\text { Pendapatan Daerah } \\
(\mathbf{R p})\end{array}$ & $\begin{array}{c}\text { Sumbangan PAD } \\
\text { terhadap Pendapatan } \\
\text { Daerah (\%) }\end{array}$ \\
\hline 2012 & $67.050 .781 .893,09$ & & - & $1.076 .501 .995 .407,09$ & 6,23 \\
2013 & $83.427 .447 .822,42$ & $/$ & 24,42 & $1.242 .092 .675 .330,20$ & 6,72 \\
2014 & $159.304 .338 .220,22$ & $/$ & 90,95 & $1.372 .846 .295 .853,34$ & 11,60 \\
2015 & $196.099 .244 .204,02$ & $/$ & 23,10 & $1.599 .005 .995 .104,47$ & 12,26 \\
2016 & $206.278 .865 .615,67$ & $/$ & 5,19 & $1.654 .344 .836 .987,14$ & 12,47 \\
2017 & $271.370 .043 .388,71$ & $/$ & 31,55 & $1.847 .105 .418 .583,10$ & 14,69 \\
2018 & $218.658 .616 .213,37$ & $/-19,42$ & $1.726 .653 .510 .860,30$ & 12,66 \\
\hline Rata-rata & $\mathbf{1 7 1 . 7 4 1 . 3 3 3 . 9 3 2 , 6 4}$ & $\mathbf{2 5 , 9 7}$ & $\mathbf{1 . 5 0 2 . 6 5 0 . 1 0 4 . 0 1 7 , 9 5}$ & $\mathbf{1 1 , 7 3}$ \\
\hline
\end{tabular}

Sumber: BKAD Kabupaten Gunungkidul (2019).

Tabel 1 menunjukkan bahwa selama kurun waktu tahun 2012-2018, rata-rata PAD Kabupaten Gunungkidul mengalami peningkatan (shift) sebesar Rp25.267.972.415,21 $(25,97 \%)$. Data tersebut menunjukkan derajad desentralisasi fiskal kategori kurang karena pendapatan daerah ditopang sebagian besar oleh dana transfer pemerintah pusat kepada daerah (Tangkilisan, 2007). Sesuai pandangan Mohamed (2017) dan Cruz et al. (2018) bahwa penerimaan daerah belum optimal dan terjadi ketergantungan keuangan daerah terhadap pemerintah pusat. Tingkat ketergantungan keuangan terhadap pemerintah pusat masih dominan. Pada tahun 2013-2014, peningkatan PAD mencapai nilai paling besar, yaitu Rp75.876.890.929,33 (90,95\%). Namun, PAD tahun 2017-2018 mengalami penurunan sebesar Rp52.711.427.004,34 (19,42\%). Data kontribusi PAD terhadap pendapatan daerah terendah terjadi pada tahun 2012 dan diikuti tahun 2013. Sumbangan PAD terbesar terjadi pada tahun 2017 sebesar 14,69\%, sedangkan kontribusi (share) PAD terhadap pendapatan daerah menggambarkan derajad desentralisasi fiskal tahun 2012-2018 rata-rata sebesar 11,73\%. Derajad desentralisasi fiskal dihitung berdasarkan perbandingan antara jumlah PAD dengan total pendapatan daerah (Putra, 2018).

Capaian pendapatan tersebut berasal dari 12 (dua belas) organisasi perangkat daerah (OPD) pengampu pendapatan di Kabupaten Gunungkidul, yaitu RSUD Wonosari, Badan Keuangan dan Aset Daerah (BKAD), Dinas Kelautan dan Perikanan, Dinas Kesehatan, Dinas Perhubungan, Dinas Pekerjaan Umum, Perumahan Rakyat, dan Kawasan Permukiman (DPUPRKP), Dinas Pariwisata, Dinas Perindustrian dan Perdagangan (Disperindag), Dinas Komunikasi dan Informatika (Diskominfo), Dinas Penanaman Modal dan Pelayanan Terpadu (DPMPT), Dinas Pertanian dan Pangan, dan Dinas Lingkungan Hidup. PAD berasal dari hasil pajak daerah, hasil retribusi daerah, hasil pengelolaan kekayaan daerah yang dipisahkan, dan lain-lain PAD yang sah. Komponen pertama, analisis terhadap hasil pajak daerah disajikan pada Tabel 2 berikut ini. 
Tabel 2. Pajak Daerah Kabupaten Gunungkidul Tahun 2012-2018

\begin{tabular}{cccc}
\hline \multirow{2}{*}{ Tahun } & Pajak Daerah & \multicolumn{2}{c}{ Pertumbuhan } \\
\cline { 3 - 4 }$(\mathbf{R p})$ & $\mathbf{R p}$ & \% \\
\hline 2012 & $10.728 .490 .356,00$ & $1.622 .186 .483,00$ & - \\
2013 & $12.350 .676 .839,00$ & $16.126 .998 .024,50$ & 130,58 \\
2014 & $28.477 .674 .863,50$ & $7.700 .561 .058,42$ & 27,04 \\
2015 & $36.178 .235 .921,92$ & $1.365 .782 .368,08$ & 3,78 \\
2016 & $37.544 .018 .290,00$ & $6.142 .027 .505,82$ & 16,36 \\
2017 & $43.686 .045 .795,82$ & $7.612 .969 .375,18$ & 17,43 \\
2018 & $51.299 .015 .171,00$ & $\mathbf{6 . 7 6 1 . 7 5 4 . 1 3 5 , 8 3}$ & $\mathbf{3 5 , 0 5}$ \\
\hline Rata-rata & $\mathbf{3 1 . 4 6 6 . 3 0 8 . 1 7 6 , 7 5}$ & &
\end{tabular}

Sumber: Analisis hasil penelitian (2019).

Berdasarkan Tabel 2, hasil pajak daerah rata-rata tumbuh 35,05\%. Peningkatan terbesar terjadi pada periode tahun 2013-2014 sebesar 130,58\%. Komponen kedua PAD, yaitu hasil retribusi daerah dijelaskan pada Tabel 3 berikut ini.

Tabel 3. Retribusi Daerah Kabupaten Gunungkidul Tahun 2012-2018

\begin{tabular}{ccrr}
\hline \multirow{2}{*}{ Tahun } & $\begin{array}{c}\text { Retribusi Daerah } \\
(\mathbf{R p})\end{array}$ & $\mathbf{c}$ & \multicolumn{2}{c}{ Pertumbuhan } \\
\cline { 3 - 4 } & $19.667 .336 .377,00$ & - & - \\
2012 & $25.024 .939 .544,00$ & $5.357 .603 .167,00$ & 27,24 \\
2013 & $25.682 .892 .167,00$ & $657.952 .623,00$ & 2,63 \\
2014 & $28.059 .628 .030,30$ & $2.376 .735 .863,30$ & 9,25 \\
2015 & $32.082 .077 .804,95$ & $4.022 .449 .774,65$ & 14,34 \\
2016 & $34.783 .664 .615,00$ & $2.701 .586 .810,05$ & 8,42 \\
2017 & $36.061 .984 .696,00$ & $1.278 .320 .081,00$ & 3,68 \\
2018 & $\mathbf{2 8 . 7 6 6 . 0 7 4 . 7 4 7 , 7 5}$ & $\mathbf{2 . 7 3 2 . 4 4 1 . 3 8 6 , 5 0}$ & $\mathbf{1 0 , 9 3}$ \\
\hline Rata-rata & & & \\
\hline
\end{tabular}

Sumber: Analisis hasil penelitian (2019).

Hasil retribusi daerah mengalami peningkatan rata-rata sebesar $10,93 \%$. Peningkatan tertinggi terjadi pada tahun 2012-2013 sebesar 27,24\%. Pertumbuhan terendah pada tahun 2013-2014 sebesar 2,63\%. Selanjutnya, komponen ketiga PAD adalah hasil pengelolaan daerah yang dipisahkan disajikan pada Tabel 4 berikut ini.

Hasil pengelolaan daerah yang dipisahkan mengalami peningkatan rata-rata $18,81 \%$. Persentase peningkatan terbesar pada tahun 2014-2015 sebesar 33,32\% dan diikuti tahun 2012-2013 sebesar 27,88\%. Pada tahun 2016-2017, pertumbuhan terkecil adalah 1,14\% dan diikuti tahun 2017-2019 sebesar 11,74\%. Komponen PAD keempat adalah lain-lain PAD yang sah disajikan pada Tabel 5 berikut ini.

Pertumbuhan lain-lain PAD yang sah terbesar pada tahun 2013-2014 sebesar $147,74 \%$ diikuti tahun 2016-2017 sebesar 45,35\%. Tahun 2017-2018 terjadi pertumbuhan negatif sebesar 35,11\% dan diikuti tahun 2015-2016 sebesar 2,01\%. Data dari keempat sumber PAD menunjukkan bahwa secara berturut-turut persentase rata- 
rata peningkatan mulai dari yang terbesar adalah hasil pajak daerah, lain-lain PAD yang sah, hasil pengelolaan daerah yang dipisahkan, dan retribusi daerah. Ringkasan hasil tersebut disajikan pada Tabel 6 .

Tabel 4. Pengelolaan Daerah yang Dipisahkan Tahun 2012-2018

\begin{tabular}{cccr}
\hline \multirow{2}{*}{ Tahun } & Pengelolaan Daerah & \multicolumn{2}{c}{ Pertumbuhan } \\
\cline { 3 - 4 } yang Dipisahkan $(\mathbf{R p})$ & $\mathbf{R p}$ & \% \\
\hline 2012 & $5.329 .404 .405,12$ & $1.485 .913 .511,13$ & 27,88 \\
2013 & $6.815 .317 .916,25$ & $1.124 .005 .774,81$ & 16,49 \\
2014 & $7.939 .323 .691,06$ & $2.645 .370 .379,87$ & 33,32 \\
2015 & $10.584 .694 .070,93$ & $2.356 .257 .265,68$ & 22,26 \\
2016 & $12.940 .951 .336,61$ & $148.047 .953,72$ & 1,14 \\
2017 & $13.088 .999 .290,33$ & $1.537 .003 .109,67$ & 11,74 \\
2018 & $14.626 .002 .400,00$ & $\mathbf{1 . 5 4 9 . 4 3 2 . 9 9 9 , 1 5}$ & $\mathbf{1 8 , 8 1}$ \\
\hline Rata-rata & $\mathbf{1 0 . 1 8 9 . 2 4 1 . 8 7 2 , 9 0}$ & & \\
\hline
\end{tabular}

Sumber: Analisis hasil penelitian (2019).

Tabel 5. Lain-lain PAD yang Sah Tahun 2012-2018

\begin{tabular}{ccrr}
\hline \multirow{2}{*}{ Tahun } & Lain-lain PAD Yang Sah $(\mathbf{R p})$ & \multicolumn{2}{c}{ Pertumbuhan } \\
\cline { 3 - 4 } & & \multicolumn{1}{c}{$\mathbf{R p}$} & - \\
2012 & $31.325 .550 .754,97$ & $7.910 .962 .768,20$ & 25,25 \\
2013 & $39.236 .513 .523,17$ & $57.967 .933 .975,49$ & 147,74 \\
2014 & $97.204 .447 .498,66$ & $24.072 .238 .682,21$ & 24,76 \\
2015 & $121.276 .686 .180,87$ & $2.435 .132 .003,24$ & 2,01 \\
2016 & $123.711 .818 .184,11$ & $56.099 .515 .503,45$ & 45,35 \\
2017 & $179.811 .333 .687,56$ & $-63.139 .719 .570,19$ & $-35,11$ \\
2018 & $116.671 .614 .117,37$ & $\mathbf{1 4 . 2 2 4 . 3 4 3 . 8 9 3 , 7 3}$ & $\mathbf{3 5 , 0 0}$ \\
\hline Rata-rata & $\mathbf{1 0 1 . 3 1 9 . 7 0 9 . 1 3 5 , 2 4}$ & &
\end{tabular}

Sumber: Analisis hasil penelitian (2019).

Berdasarkan hasil penelitian tersebut di atas, perkembangan komponen PAD selama periode 2012-2018 diuraikan sebagai berikut:

Pertama, pendapatan pajak daerah tahun 2014 mengalami peningkatan sebesar 130,58\%. PBB-P2 meningkat karena adanya kebijakan pelimpahan wewenang pengelolaan dan pemungutan PBB-P2 dan BPHTB dari Dirjen Pajak Kementerian Keuangan kepada daerah, sehingga menjadi sumber pemasukan daerah. Hal tersebut sesuai Peraturan Bersama Menteri Keuangan dan Menteri Dalam Negeri No. 15/PMK.07/2014 dan No. 10 Tahun 2014 tentang Tahapan Persiapan Pengalihan PBBP2 menjadi Pajak Daerah. Untuk meningkatkan pajak sektor pariwisata, pendapatan pajak hotel dan restoran perlu diintensifkan dan tidak hanya fokus pada retribusi. Hal tersebut sesuai pandangan Sitompul et al. (2014), yaitu peningkatan sistem administrasi perpajakan, peningkatan kualitas petugas, upaya pajak secara intensif, dan menerapkan imbalan dan hukuman. 
Tabel 6. Sebaran Perkembangan Komponen PAD Tahun 2012 - 2018

\begin{tabular}{|c|c|c|c|c|c|c|c|c|}
\hline \multirow{2}{*}{$\begin{array}{c}\text { Jenis } \\
\text { Sumber PAD }\end{array}$} & \multirow{2}{*}{$\begin{array}{c}\text { Rerata Peningkatan } \\
(\%)\end{array}$} & \multicolumn{7}{|c|}{ Ranking Peningkatan } \\
\hline & & 2012 & 2013 & 2014 & 2015 & 2016 & 2017 & 2018 \\
\hline 1. Pajak daerah & 35,05 & & 5 & 1 & 2 & 6 & 4 & 3 \\
\hline 2. Retribusi daerah & 10,93 & & 1 & 6 & 3 & 2 & 4 & 5 \\
\hline $\begin{array}{l}\text { 3. Hasil pengelolaan } \\
\text { daerah yang dipisahkan }\end{array}$ & 18,81 & & 2 & 4 & 1 & 3 & 6 & 5 \\
\hline $\begin{array}{l}\text { 4. Lain-lain PAD yang } \\
\text { Sah }\end{array}$ & 35,00 & & 3 & 1 & 4 & 5 & 2 & 6 \\
\hline
\end{tabular}

Sumber: Analisis hasil penelitian (2019).

Keterangan:

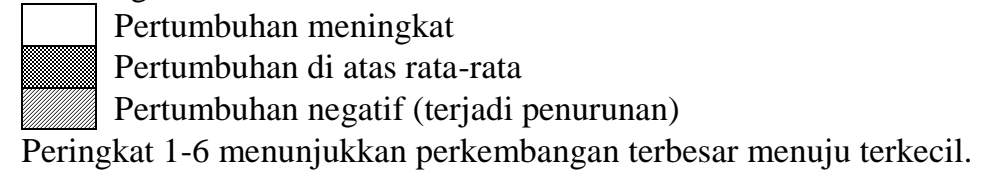

Kedua, pendapatan retribusi daerah tahun 2013 dan 2016 berada di atas rata-rata. Namun, retribusi pada tahun 2017 dan 2018 mengalami penurunan. Pada tahun 2018, target pendapatan retribusi pariwisata Rp28.276.144.000 hanya tercapai sebesar Rp24.243.414.350. Hal ini disebabkan faktor isu bencana alam di pantai yang terjadi di daerah lain dan bencana banjir yang mempengaruhi niat dan persepsi wisatawan berkunjung ke Gunungkidul. Meskipun mengalami penurunan, retribusi sektor pariwisata berperan dalam pendapatan, karena kontribusinya terhadap PAD cukup tinggi. Pada sisi lain, yang harus diperhatikan adalah penarikan pajak hotel dan restoran (Sitompul et al., 2014) dan tidak hanya memungut retribusi pariwisata. Data DPUPRKP menunjukkan target penerimaan hanya mencapai 67,61\% dari target Rp585.571.136. Faktor penyebabnya adalah: (1) Target sewa rusunawa tidak terpenuhi karena waktu penyusunan PAD sewa rusunawa tahun 2018 tarif perhitungannya lebih tinggi. Dasar pemberlakuan adalah Perbup No. 40 Tahun 2017 besaran tarif lebih rendah; (2) Ruang komersial belum dilengkapi sarana prasarana memadai, seperti sarana air bersih, saluran air kotor, Instalasi Pengolahan Air Limbah (IPAL), dan bangunan masih dalam tahap penyempurnaan; dan (3) Penghuni rusunawa keluar masuk yang mengakibatkan kurang lancarnya penerimaan sewa rusunawa.

Ketiga, hasil pengelolaan daerah yang dipisahkan mengalami rata-rata peningkatan sebesar $18,81 \%$. Peningkatan di atas rata-rata berturut-turut dari yang terbesar adalah pada tahun 2015, 2013, dan 2016, yaitu naiknya deviden daerah dari PT Bank BPD dan PD BPR BDG.

Keempat, kontribusi lain-lain PAD yang sah mengalami dinamika yang menarik. Pertama, pada tahun 2014 mengalami peningkatan sebesar 147,74\%. Salah satu faktor yang menyebabkan adalah lonjakan dana kapitasi kompensasi pelayanan Badan Layanan Umum Daerah Rumah Sakit Umum Daerah (BLUD RSUD) dan Pusat Kesehatan Masyarakat (Puskesmas) dari Badan Penyelenggara Jaminan Sosial (BPJS) Kesehatan; Kedua, pada tahun 2017 terjadi peningkatan di atas rata-rata karena dana Biaya Operasional Sekolah (BOS) masuk pada komponen tersebut; dan Ketiga, pada tahun 2018 mengalami penurunan. Faktor penyebabnya adalah dana BOS pada tahun 2017 masuk klasifikasi Lain-lain PAD yang sah. Berdasarkan Surat Edaran Menteri Dalam Negeri (Mendagri) No. 910/106/SJ tanggal 11 Januari 2017 tentang Petunjuk 
Teknis Penganggaran, Pelaksanaan, dan Penatausahaan, serta Pertanggungjawaban Dana BOS Satuan Pendidikan Negeri yang Diselenggarakan oleh Kabupaten/Kota pada APBD mengatur bahwa pendapatan Dana BOS dianggarkan pada PAD dalam kategori Jenis Lain-lain PAD yang sah (Kementerian Dalam Negeri RI, 2017). Namun, setelah tahun 2017 terjadi perubahan kebijakan, yaitu dana BOS masuk rekening Lain-lain Pendapatan Daerah yang Sah berdasarkan Peraturan Mendagri No. 134 Tahun 2018 (Kementerian Dalam Negeri RI, 2018). Pengalaman pendapatan dana kapitasi BPJS Kesehatan dan BOS Kementerian Pendidikan dan Kebudayaan (Kemendikbud), sesuai pandangan Mohamed (2017) dan Cruz et al. (2018) bahwa sumber-sumber keuangan daerah atau PAD belum optimal menopang pendapatan dan terjadi ketergantungan keuangan daerah pada pemerintah pusat. Sebagian dana kapitasi BPJS Kesehatan yang diterima Pemda merupakan imbal balik belanja premi yang dibayarkan Pemda kepada BPJS kesehatan.

Analisis data dalam penelitian ini menunjukkan bahwa PAD Kabupaten Gunungkidul mengalami peningkatan, tetapi belum signifikan, stabil, dan aman dalam menopang keuangan daerah. Kondisi tersebut dapat diuraikan sebagai berikut:

1) Peningkatan penerimaan pada komponen PAD dipengaruhi dan tergantung pada kebijakan pemerintah pusat. Hal tersebut sesuai pandangan Cruz et al. (2018) tentang ketergantungan keuangan daerah pada pemerintah pusat, yaitu: Pertama, penerimaan PBB-P2 meningkat tajam pada tahun 2014 karena kebijakan pemerintah pusat mendaerahkan PBB-P2, menggeser pendapatan pajak pusat menjadi pajak daerah; Kedua, tahun 2014 pada lain-lain PAD yang sah mengalami peningkatan sebesar 147,74\% karena alokasi dana kapitasi yang diberikan oleh BPJS sebagai kompensasi pelayanan dasar dan rujukan di BLUD Puskesmas dan RSUD. Pendapatan BLUD langsung digunakan untuk mengganti biaya pelayanan dan tidak boleh untuk membiayai kegiatan investasi; Ketiga, komponen PAD secara akuntansi tidak tepat dalam memasukkan kode rekening pendapatan, yaitu dana BOS masuk PAD (komponen lain-lain PAD yang sah), sementara secara regulasi dana BOS bukan bagian dari PAD. Penempatan dana BOS sesuai kebijakan Kemendikbud sebagai rekening penampungan untuk menghindari hibah langsung ke sekolah.

2) Peningkatan PAD dengan kondisi sangat rentan (vulnerable) atas pengaruh situasi tertentu sebagaimana pandangan Mohamed (2017) menyatakan bahwa keuangan daerah mengalami banyak tantangan yang harus mampu dipecahkan oleh daerah. Khususnya, PAD retribusi rekreasi dan olahraga yang dikelola Dinas Pariwisata. Pada kurun waktu sebelumnya selama 5 (lima) tahun mengalami peningkatan tetapi pada tahun 2018 mengalami penurunan karena terdampak isu bencana alam di luar Kabupaten Gunungkidul. Persepsi wisatawan datang berkunjung ke Kabupaten Gunungkidul dan citra destinasi wisata turut mempengaruhi penerimaan retribusi pariwisata.

3) Adanya komponen PAD yang mengalami stagnasi karena regulasi (Perda dan Perbup) yang mengatur dasar pemungutan sudah kadaluwarsa (out of to date). Contohnya, tarif parkir motor hanya senilai Rp500. Sesuai pandangan Mardiasmo (2002), untuk meningkatkan pendapatan agar berjalan secara optimal diperlukan kajian peningkatan tarif dan penjualan jasa publik (charging for services), sehingga sudah saatnya untuk melakukan peninjauan tarif. 
4) Adanya piutang pajak dan retribusi, sehingga pendapatan tidak maksimal. Contohnya, PBB-P2 terdapat piutang, pajak reklame belum dibayar, reklame sudah dipasang tetapi belum berizin, dana PBB-P2 yang dipungut perangkat desa belum disetor ke kas daerah, dan retribusi Izin Mendirikan Bangunan (IMB) sudah diterbitkan izinnya tetapi dokumen belum atau tidak diambil oleh pemohon dan retribusinya belum dibayar. Mardiasmo (2002) menyatakan perlunya peningkatan pengawasan dan penerapan sanksi pada penunggak, serta perbaikan administrasi pendapatan. Upaya itu perlu dilakukan agar pendapatan diperoleh dengan cepat dan didukung oleh sistem informasi pendapatan daerah.

5) Kontribusi pajak lebih besar dibandingkan pendapatan retribusi. Namun, kontribusi pajak belum signifikan dan masih mengandalkan PBB-P2 dan belum mendasarkan obyek pajak lain. Penghasilan pajak disebabkan kebijakan pengalihan PBB-P2 dari pendapatan pemerintah pusat atau pendaerahan pajak. Potensi pajak selain PBB-P2 yang cukup potensial adalah pajak restoran/rumah makan dan pajak hotel belum berkontribusi signifikan pada PAD seiring dengan perkembangan pariwisata. Penentuan tarif pemungutan harus tepat. Hal tersebut untuk menghindarkan penerapan pajak sektor pariwisata yang dapat mematikan pariwisata itu sendiri. Oleh karena itu, penetapan sistem pajak yang tepat mendorong sektor pariwisata bisa berkembang dengan pesat (Ylvije \& Elez, 2012).

6) Belum ada upaya Pemda untuk mendayagunakan aset daerah menjadi sumber pendapatan (passive income dari aset). Hanya terdapat dua sumber pendapatan yang berasal dari pendayagunaan aset, yaitu berupa sewa tanah Stasiun Pengisian Bahan Bakar Umum (SPBU) dan sewa Gedung Olah Raga (GOR) Siyono untuk rumah makan Gunungkidul Steak (GK Steak). Selain itu, masih adanya tanah milik Pemda yang belum dimanfaatkan secara optimal.

Menurut Mohamed (2017), optimalisasi pendapatan daerah memerlukan strategi pengumpulan pendapatan yang optimal dan didukung sistem informasi pendapatan daerah. Pandangan Karimi et al. (2017), Otieno et al. (2013), Githinji et al. (2014) dan Olatunji dan Ayodele (2017) menekankan pentingnya penggunaan sistem informasi, teknologi informasi dan komunikasi, serta adopsi teknologi dalam optimalisasi pendapatan yang signifikan.

\section{Analisis Kekuatan, Kelemahan, Peluang, dan Ancaman (SWOT) PAD Kabupaten Gunungkidul}

Analisis isu-isu strategis berdasarkan aspek internal dan eksternal mencakup kekuatan, kelemahan, peluang, dan ancaman disajikan pada Tabel 7-9 berikut ini.

\section{Tabel 7. Analisis Kekuatan, Kelemahan, Peluang dan Ancaman (SWOT)}

\begin{tabular}{|c|c|c|}
\hline \multicolumn{2}{|r|}{ KEKUATAN (S) } & KELEMAHAN (W) \\
\hline 1) & $\begin{array}{l}\text { Potensi pajak dan retribusi daerah di berbagai } \\
\text { sector. }\end{array}$ & $\begin{array}{l}\text { Kompetensi dan komitmen petugas } \\
\text { pemungut pendapatan rendah. }\end{array}$ \\
\hline 2) & Trend pertumbuhan PAD meningkat periode & Pemungutan PAD belum online. \\
\hline & tahun 2012-2018. & Data base dan perencanaan penerimaan \\
\hline 3) & Regulasi dan tarif PAD. & pajak retribusi belum akurat. \\
\hline 4) & Tersedia anggaran pemungutan PAD & Tarif pajak daerah kadaluwarsa. \\
\hline 5) & $\begin{array}{l}\text { Pemungutan PAD secara online didukung } \\
\text { closed circuit television (CCTV). }\end{array}$ & $\begin{array}{l}\text { Aset Pemda belum optimal sebagai passive } \\
\text { income. }\end{array}$ \\
\hline
\end{tabular}




\begin{tabular}{|c|c|c|}
\hline \multicolumn{2}{|r|}{ KEKUATAN (S) } & KELEMAHAN $(\mathbf{W})$ \\
\hline 6) & Cash opname PAD secara berkala. & 6) SOP pemungutan pajak dan retribusi \\
\hline 7) & Penambahan obyek wisata yang ditarik & tumpang tindih. \\
\hline 8) & $\begin{array}{l}\text { retribusi tempat rekreasi dan olahraga. } \\
\text { Layanan onlinecellplan.gunungkidulkab.go.id } \\
\text { mempermudah estimasi retribusi. }\end{array}$ & $\begin{array}{l}\text { 7) IMB belum online single submission (OSS). } \\
\text { 8) } 52 \% \text { wilayah adalah kawasan lindung } \\
\text { geologi membatasi investasi. }\end{array}$ \\
\hline \multicolumn{2}{|r|}{ PELUANG $(\mathbf{O})$} & ANCAMAN $(T)$ \\
\hline 1) & $\begin{array}{l}\text { Kawasan strategis pariwisata dengan obyek } \\
\text { wisata mampu menarik PAD. }\end{array}$ & $\begin{array}{l}\text { 1) Kepatuhan wajib pajak-retribusi rendah, } \\
\text { sehingga terdapat tunggakan/piutang. }\end{array}$ \\
\hline 2) & Tumbuhnya investasi swasta. & 2) Kegiatan usaha belum berizin, sehingga \\
\hline 3) & Gunungsewu United Nations of Educational, & \\
\hline & $\begin{array}{l}\text { Scientific, and Cultural Organization } \\
\text { (UNESCO) Global Geopark. }\end{array}$ & $\begin{array}{l}\text { 3) Bencana alam menyebabkan minat } \\
\text { wisatawan berkunjung menurun. }\end{array}$ \\
\hline 4) & $\begin{array}{l}\text { Pengembangan Kawasan Ekonomi Khusus } \\
\text { (KEK) Pariwisata. }\end{array}$ & $\begin{array}{l}\text { 4) Kebijakan pusat menghapuskan sumber } \\
\text { PAD. }\end{array}$ \\
\hline
\end{tabular}

Sumber: Analisis hasil penelitian (2019).

Tabel 8. Matriks Internal Factor Evaluation (IFE) PAD Kabupaten Gunungkidul

\begin{tabular}{|c|c|c|c|}
\hline Faktor Internal Kunci & Bobot & Peringkat & $\begin{array}{c}\text { Skor } \\
\text { Tertimbang } \\
\end{array}$ \\
\hline \multicolumn{4}{|l|}{ Kekuatan (S) } \\
\hline $\begin{array}{l}\text { 1) Potensi pajak dan retribusi daerah } \\
\text { di berbagai sektor. }\end{array}$ & 0,088 & 4,0 & 0,352 \\
\hline $\begin{array}{l}\text { 2) Trend pertumbuhan PAD meningkat } \\
\text { tahun 2012-2018. }\end{array}$ & 0,087 & 3,9 & 0,339 \\
\hline 3) Adanya regulasi dan tarif PAD. & 0,082 & 3,8 & 0,334 \\
\hline 4) Tersedianya anggaran pemungutan PAD. & 0,076 & 3,7 & 0,322 \\
\hline 5) Pemungutan PAD secara online didukung CCTV. & 0,075 & 3,6 & 0,295 \\
\hline 6) Cash opname PAD secara berkala. & 0,060 & 3,5 & 0,266 \\
\hline $\begin{array}{l}\text { 7) Penambahan lokasi obyek wisata yang ditarik retribusi } \\
\text { tempat rekreasi dan olahraga. }\end{array}$ & 0,050 & 3,4 & 0,255 \\
\hline $\begin{array}{l}\text { 8) Layanan onlinecellplan.gunungkidulkab.go.id mempermudah } \\
\text { estimasi retribusi. }\end{array}$ & 0,047 & 3,2 & 0,192 \\
\hline \multicolumn{4}{|l|}{ Kelemahan (W) } \\
\hline $\begin{array}{l}\text { 1) Kompetensi dan komitmen SDM pemungut pendapatan } \\
\text { rendah. }\end{array}$ & 0,072 & 1,1 & 0,079 \\
\hline 2) Pemungutan PAD belum online. & 0,070 & 1,2 & 0,084 \\
\hline $\begin{array}{l}\text { 3) Data base dan perencanaan penerimaan pajak dan retribusi } \\
\text { belum akurat. }\end{array}$ & 0,063 & 1,5 & 0,095 \\
\hline 4) Tarif pajak daerah kadaluwarsa. & 0,050 & 1,9 & 0,120 \\
\hline 5) Aset Pemda belum optimal sebagai passive income. & 0,029 & 2,0 & 0,120 \\
\hline 6) SOP pemungutan pajak dan retribusi tumpang tindih. & 0,061 & 1,7 & 0,122 \\
\hline IMB belum melalui online single submission (OSS). & 0,030 & 2,0 & 0,122 \\
\hline $\begin{array}{l}\text { 8) } 52 \% \text { wilayah adalah kawasan lindung geologi, yang } \\
\text { membatasi kegiatan investasi. }\end{array}$ & 0,060 & 1,8 & 0,126 \\
\hline Total & 1,000 & & 2,535 \\
\hline
\end{tabular}

Sumber: Analisis hasil penelitian (2019).

Tabel 9. Matriks External Factor Evaluation (EFE) PAD Kabupaten Gunungkidul

\begin{tabular}{lccc}
\hline \multicolumn{1}{c}{ Faktor Eksternal Kunci } & Bobot & Peringkat & $\begin{array}{c}\text { Skor } \\
\text { Tertimbang }\end{array}$ \\
\hline $\begin{array}{l}\text { Peluang (O) } \\
\text { 1) Kawasan strategis pariwisata dengan obyek wisata }\end{array}$ & 0,140 & 4,0 & 0,560 \\
$\begin{array}{l}\text { mampu menarik PAD } \\
\text { 2) Tumbuhnya investasi swasta }\end{array}$ & 0,139 & 4,0 & 0,556 \\
\hline
\end{tabular}




\begin{tabular}{|c|c|c|c|c|}
\hline & Faktor Eksternal Kunci & Bobot & Peringkat & $\begin{array}{c}\text { Skor } \\
\text { Tertimbang }\end{array}$ \\
\hline 3) & Gunungsewu UNESCO Global Geopark & 0,130 & 3,8 & 0,494 \\
\hline 4) & $\begin{array}{l}\text { Pengembangan Kawasan Ekonomi Khusus (KEK) } \\
\text { Pariwisata }\end{array}$ & 0,127 & 3,2 & 0,406 \\
\hline \multicolumn{5}{|c|}{ Ancaman $(T)$} \\
\hline 1) & Kepatuhan wajib pajak dan retribusi rendah & 0,125 & 1,5 & 0,188 \\
\hline 2) & Kegiatan usaha belum berizin. & 0,124 & 1,6 & 0,198 \\
\hline 3) & $\begin{array}{l}\text { Bencana alam menyebabkan minat wisatawan } \\
\text { berkunjung menurun }\end{array}$ & 0,113 & 1,8 & 0,203 \\
\hline \multirow[t]{2}{*}{ 4) } & Kebijakan pusat menghapuskan sumber PAD & 0,102 & 2,0 & 0,204 \\
\hline & Total & 1,000 & & 2,745 \\
\hline
\end{tabular}

Sumber: Analisis hasil penelitian (2019).

\section{Tabel 10. Pemetaan Interaksi Faktor Internal dan Eksternal}

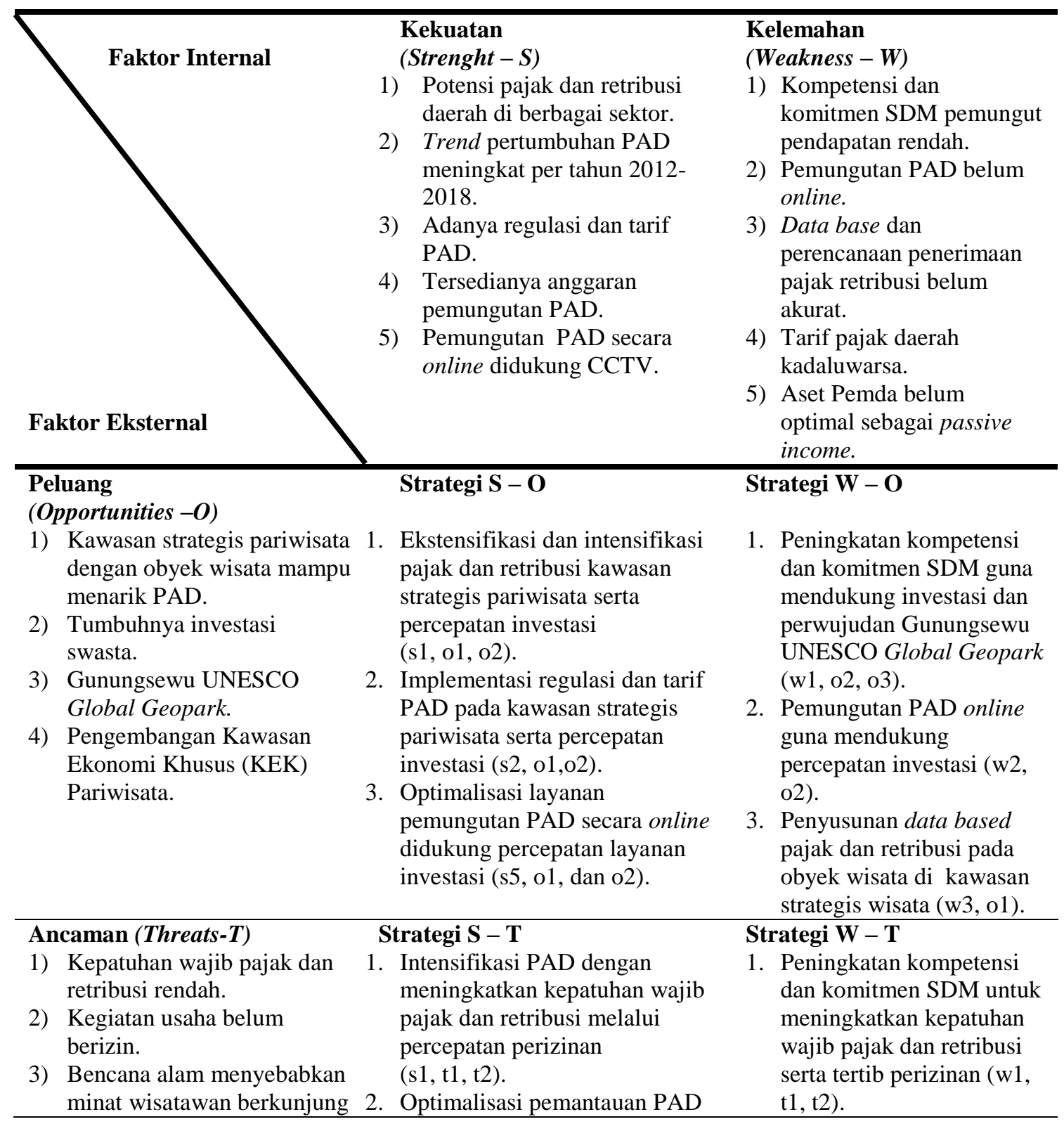




\begin{tabular}{ll}
\hline menurun. & online terintegrasi mitigasi \\
bencana $(\mathrm{s} 5, \mathrm{t} 3)$. \\
$\begin{array}{l}\text { Kebijakan pusat } \\
\text { menghapuskan berbagai }\end{array}$
\end{tabular}

Sumber: Hasil analisis SWOT (2019).

Berdasarkan hasil analisis SWOT (Tabel 10), maka strategi kebijakan dirumuskan untuk meningkatkan PAD Kabupaten Gunungkidul, yaitu:

1. Strategi Kekuatan-Peluang $(\mathrm{S}-\mathrm{O})$

a. Pengembangan dan intensifikasi obyek pajak dan retribusi pada kawasan strategis pariwisata dan percepatan investasi.

Kabupaten Gunungkidul adalah daerah tujuan wisata potensial yang berpeluang untuk pengembangan investasi. Pemda dapat mengembangkan sumber-sumber PAD dan mengintensifkan pemungutan PAD potensial terutama pada kawasan wisata. Potensi sumber PAD yang bisa diraih, antara lain: (1) Kawasan strategis potensial diintensifkan retribusinya, yaitu kawasan wisata pantai dengan menerapkan sistem satu pintu, sistem parkir terpadu, dan pembaruan sistem tiket dari sistem karcis ke e-ticketing; (2) Retribusi IMB sangat potensial, tetapi masih banyak bangunan yang belum bisa dipungut IMBnya; (3) Retribusi Surat Ijin Usaha (SIU); dan (4) Kerjasama pemanfaatan aset milik pemerintah daerah.

b. Percepatan investasi, implementasi regulasi, dan tarif pajak-retribusi pada kawasan strategis pariwisata.

Komponen pajak dan retribusi yang sudah ditetapkan dalam Perda dapat dibuatkan Standard Operating Procedure (SOP) dan dipungut, sehingga tidak terjadi piutang PAD atau kemungkinan terjadinya PAD yang hilang.

c. Optimalisasi layanan pemungutan PAD secara online didukung percepatan layanan investasi.

Layanan pemungutan PAD online dan percepatan layanan investasi wajib dilakukan agar realisasi investasi dapat berjalan lebih cepat dan potensi pendapatan lebih cepat dipungut, serta langsung masuk PAD melalui bank mitra pemerintah daerah (PT Bank BPD DIY) dengan sistem transfer non-tunai (TNT). Contohnya, retribusi IMB ditarik bersamaan saat pemohon menerima IMB satu paket dengan aplikasi perizinan dan wajib langsung transfer ke rekening kas daerah. Semakin banyaknya investasi merupakan pendukung potensi PAD yang bisa dipungut.

2. Strategi Kelemahan-Peluang (W-O)

a. Peningkatan kompetensi dan komitmen sumber daya manusia (SDM)/aparatur sipil negara guna mendukung investasi dan perwujudan Gunungsewu UNESCO Global Geopark.

SDM yang menangani pajak dan retribusi dapat ditingkatkan kompetensi dan komitmennya dalam pengelolaan PAD melalui program pendidikan dan pelatihan pajak-retribusi dan rekrutmen tenaga harian lepas (THL) bidang pajak dan retribusi secara transparan. Kegiatan ini dapat dianggarkan pada masing-masing perangkat daerah 
b. Pemungutan PAD online guna mendukung percepatan realisasi investasi.

Pemungutan PAD online dilaksanakan untuk meningkatkan kecepatan pelayanan pelanggan dan mendorong wajib pajak-retribusi semakin patuh membayar pajak dan retribusi tepat waktu, sehingga tidak terjadi piutang daerah.

c. Penyusunan basis data pajak-retribusi yang akurat pada obyek wisata di kawasan strategis wisata.

Basis data pajak-retribusi disusun dengan metode survei menggunakan sistem blok dan prioritas pada kawasan strategis wisata sebagai pusat kegiatan ekonomi berdasarkan wilayah administrasi. Pemutakhiran obyek pajak tidak hanya diprioritaskan di kawasan perkotaan saja, tetapi juga menyasar kawasan wisata. Pada umumnya, di kawasan-kawasan wisata berdiri bangunan baru, seperti hotel, rumah makan, dan homestay yang dapat menjadi potensi PBB-P2 dan dapat disesuaikan Nilai Jual Obyek Pajak (NJOP)nya.

3. Strategi Kekuatan-Ancaman $(\mathrm{S}-\mathrm{T})$

a. Intensifikasi pajak-retribusi daerah dengan meningkatkan kepatuhan (compliance) wajib pajak-retribusi melalui percepatan layanan perizinan.

Pendekatan kepatuhan diterapkan dengan sistem panutan, keteladanan, pemberian insentif, dan penghargaan kepada para wajib pajak-retribusi yang membayar tepat waktu dan memberikan sanksi kepada wajib pajak-retribusi yang tidak patuh membayar. Intensifikasi pajak-retribusi daerah dipacu melalui percepatan layanan perizinan dengan prosedur ketika izin sudah diterbitkan, maka secara resmi telah dipungut pajak-retribusi (perubahan dari sistem cash basis ke accrual basis). Ketika pelaku usaha telah beroperasi, maka potensi pajak-retribusi yang dipungut semakin besar dan meningkat dari tahun ke tahun. Contohnya, pajak reklame dipungut ketika pelaku usaha mengajukan izin pemasangan iklan pada tempat-tempat yang diperkenankan oleh Perda.

b. Optimalisasi pemantauan online (digitalisasi) PAD terintegrasi mitigasi bencana alam wisata pantai.

Strategi digitalisasi pada era teknologi informasi sebagai kebutuhan, termasuk pada pengelolaan PAD. Sebagian besar karakter obyek wisata Kabupaten Gunungkidul adalah kawasan wisata pantai, seperti Pantai Baron, Kukup, Krakal, Drini, Siung, dan Sepanjang, yang potensial dipungut retribusi rekreasi dan olahraga, merupakan kawasan rawan bencana gelombang pasang dan tsunami. Retribusi dan mitigasi bencana memerlukan digitalisasi agar informasi kejadian segera dapat diantisipasi dan diselesaikan dengan cepat. Pemasangan kamera CCTV yang tersentral dan dikendalikan Network Operation Center (NOC) pada kawasan wisata memudahkan petugas pungut retribusi, BKAD, dan Badan Penanggulangan Bencana Daerah (BPBD) memonitor situasi obyek wisata secara real time. Pemasangan kamera CCTV pada pos retribusi mengantisipasi kebocoran atau penyimpangan tiket/karcis retribusi karena semua aktifitas terekam audio visual CCTV secara online.

4. Strategi Kelemahan-Ancaman (W-T)

Peningkatan kompetensi dan komitmen aparatur sipil negara guna meningkatkan kepatuhan wajib pajak dan retribusi, serta tertib perizinan usaha. 
Berpijak pada faktor kelemahan SDM, upaya peningkatan kompetensi dan komitmen SDM diperlukan melalui pendidikan pelatihan intensif, seperti pelatihan pemetaan dan perhitungan $\mathrm{PBB}-\mathrm{P} 2$, penentuan NJOP, penilaian property, dan pemutakhiran data obyek pajak.

Berdasarkan strategi yang telah dirumuskan, selanjutnya rencana aksi peningkatan PAD Kabupaten Gunungkidul disusun dalam Tabel 11, sebagai berikut:

\section{Tabel 11. Rencana Aksi Peningkatan PAD Kabupaten Gunungkidul}

No Uraian Rencana Aksi

1. Pengkajian pengembangan potensi PAD.

2. Pengkajian Perda yang kadaluwarsa dan penyusunan regulasi baru (Perda dan Perbup) yang up to date.

3. Penyusunan standar operating procedure (SOP) pemungutan dan penagihan pajak-retribusi.

4. Sosialisasi pajak-retribusi (pemasangan spanduk, banner, baliho, siaran radio, dan talkshow radio) .

5. Peningkatan kompetensi dan komitmen SDM bidang pajak- retribusi:

a. Pelatihan pemetaan dan penilaian obyek PBB-P2 bekerjasama dengan Badan Pertanahan Nasional (BPN) dan Sekolah Tinggi Pertanahan Nasional (STPN)

b. Penilaian properti.

6. Intensifikasi PAD:

a. Penyusunan basis data obyek PAD (hotel, homestay, rumah makan, dan reklame).

b. Review PAD secara periodik (1 bulan sekali).

c. Pemungutan pajak terpadu online (e-pajak).

d. Tanda tangan digital Surat Pemberitahuan Pajak Terhutang (SPPT) PBB.

e. Pemungutan retribusi terpadu online (e-retribusi) seperti: $e$-retribusi pasar, $e$-retribusi wisata $(e-$ ticketing).

f. Pemberian insentif 5\% atas pencapaian target pajakretribusi pada pengelola/petugas PAD.

g. Kerjasama pemanfaatan aset Pemda agar mendatangkan PAD, yaitu: perjanjian sewa, Kerjasama Pemerintah Badan Usaha (KPBU), bangun serah guna rest area/sarana wisata, dan obyek vital daerah.

h. Penyelenggaraan event wisata, yaitu: Gunungsewu Festival, Gunungkidul Festival, Festival Akhir Tahun, dan lain-lain.

7. Peningkatan kualitas pelayanan perizinan online (tanda tangan digital, aplikasi perizinan, dan siap antar perizinan-non-perizinan).

8. Penagihan piutang pajak-retribusi

\section{Pihak Terkait/} Perangkat Daerah

BAPPEDA, Bagian Administrasi

Perekonomian dan SDA Sekretariat Daerah (Setda), BKAD, Perguruan Tinggi/Pakar/Dewan Riset Daerah (DRD)

DPRD, Bagian Hukum Setda, Bagian Administrasi Perekonomian Setda, BKAD, Perguruan Tinggi. BKAD, Bagian Hukum Setda, Bagian Organisasi Setda, Bagian Administrasi Perekonomian dan SDA Setda.

BKAD, Dinas Kominfo, Radio Suara Dhaksinarga, Bagian Administrasi Perekonomian dan SDA Setda.

BKAD, BPN, STPN,

Badan Kepegawaian, Pendidikan, dan Pelatihan Daerah (BKPPD)

BKAD, Inspektorat Daerah, Dinas Pariwisata, Bagian Administrasi Perekonomian dan SDA Setda, Dinas Kominfo, Lembaga Sandi Negara (Lemsaneg),

Dinas Penanaman Modal dan Pelayanan Terpadu (DPMPT), Semua Dinas Pengelola PAD, PT Bank BPD, Notaris.

DPMPT, Bagian Organisasi Setda, Lemsaneg, Dinas Kominfo.

BKAD, DPMPT, DUPRKP, Satuan 


\begin{tabular}{|c|c|c|}
\hline No & Uraian Rencana Aksi & $\begin{array}{c}\text { Pihak Terkait/ } \\
\text { Perangkat Daerah }\end{array}$ \\
\hline 9. & $\begin{array}{l}\text { Peningkatan kepatuhan wajib pajak dan retribusi: } \\
\text { a. Operasi pro justisia perizinan (pajak reklame, PJU, } \\
\text { izin trayek, KIR Kendaraan, IMB, dan lain-lain) } \\
\text { b. Pekan panutan wajib pajak } \\
\text { c. Penghargaan pada wajib pajak } \\
\text { d. Pemberian sanksi pada wajib pajak dan retribusi yang } \\
\text { belum/tidak membayar termasuk petugas pungut } \\
\text { yang belum menyetorkan pajak }\end{array}$ & $\begin{array}{l}\text { Polisi Pamong Praja (Satpol PP), } \\
\text { semua dinas pengelola PAD, PT } \\
\text { Bank BPD, Bank BDG, Inspektorat } \\
\text { Daerah. } \\
\text { SatPol PP, BKAD, Dinas } \\
\text { Perhubungan, DPMPT, } \\
\text { DPUPRKP, PT Bank BPD, Bank } \\
\text { BDG, Inspektorat Daerah, Bagian } \\
\text { Hukum Setda. }\end{array}$ \\
\hline 10. & $\begin{array}{l}\text { Pemungutan PAD secara online (digitalisasi) dan } \\
\text { didukung kamera CCTV pada obyek wisata (pos } \\
\text { retribusi, tempat parkir, dan kawasan pantai rawan } \\
\text { bencana) }\end{array}$ & $\begin{array}{l}\text { Dinas Kominfo, Dinas } \\
\text { Perhubungan, Dinas Pariwisata, } \\
\text { BPBD. }\end{array}$ \\
\hline 11 & $\begin{array}{l}\text { Peningkatan koordinasi perencanaan dan pengawasan } \\
\text { melalui: } \\
\text { a. Forum perangkat daerah fungsi pendapatan } \\
\text { b. Penetapan target PAD yang realistis }\end{array}$ & $\begin{array}{l}\text { BAPPEDA, BKAD, Tim Anggaran } \\
\text { Pemerintah Daerah (TAPD). }\end{array}$ \\
\hline 12. & $\begin{array}{l}\text { Pembangunan infrastruktur teknologi informatika dan } \\
\text { komunikasi (infrastruktur jaringan, integrasi internet } \\
\text { antar OPD sampai desa, dan pembuatan aplikasi } \\
\text { pemungutan PAD) }\end{array}$ & $\begin{array}{l}\text { Dinas Kominfo, BKAD, } \\
\text { Pemerintah Desa. }\end{array}$ \\
\hline
\end{tabular}

Strategi dan rencana aksi tersebut merupakan rencana organisasi perangkat daerah yang dilaksanakan secara terpadu serta terkoordinasi untuk mencapai sasaran peningkatan PAD. Formulasi strategi dan rencana aksi dilakukan dengan mengintegrasikan faktor-faktor kunci keberhasilan organisasi agar tercipta sinergi pencapaian tujuan dan sasaran sesuai pedoman Lembaga Administrasi Negara (2008).

\section{KESIMPULAN DAN SARAN}

PAD Kabupaten Gunungkidul meliputi pajak daerah, retribusi daerah, hasil pengelolaan kekayaan yang dipisahkan, dan lain-lain PAD yang sah. Selama kurun waktu tahun 2012-2018, PAD Kabupaten Gunungkidul mengalami pertumbuhan (shift) rata-rata sebesar 25,97\%. Sumbangan (share) PAD terhadap pendapatan daerah menggambarkan derajad desentralisasi fiskal selama kurun waktu tahun 2012-2018 rata-rata sebesar $11,73 \%$. Beberapa obyek PAD mengalami peningkatan dan penurunan. Strategi peningkatan PAD yang mendasarkan pada kekuatan, kelemahan, peluang, dan ancaman diformulasikan menjadi strategi dan rencana aksi peningkatan PAD untuk diimplementasikan perangkat daerah terkait.

Berdasar hasil penelitian ini, Pemerintah Kabupaten Gunungkidul disarankan untuk: Pertama, meningkatkan kompetensi serta komitmen sumber daya manusia pengelola pajak-retribusi yang dianggarkan oleh masing-masing perangkat daerah pengelola pendapatan; Kedua, menyusun program peningkatan PAD dan implementasi rencana aksi peningkatan PAD secara konsisten; Ketiga, memanfaatkan teknologi informasi dan komunikasi, sistem informasi, digitalisasi, dan pemungutan PAD online 
missalnya e-ticketing; dan Keempat, mengoptimalkan kerjasama antarpihak. Selain itu, peneliti menyarankan agar penelitian selanjutnya dapat memfokuskan analisis faktorfaktor yang mempengaruhi kinerja PAD pada organisasi perangkat daerah pengampu pendapatan di Kabupaten Gunungkidul.

\section{DAFTAR REFERENSI}

Amalia, S. (2018). Reformasi Birokrasi 4.0: Strategi Menghadapi Revolusi Industri 4.0. Jurnal Wacana Kinerja: Kajian Praktis-Akademis Kinerja dan Administrasi Pelayanan Publik, 21(2): 0-2. https://doi.org/10.31845/jwk.v21i2.133.

Anggara, S. (2016). Administrasi Keuangan Negara (I). Bandung: CV Pustaka Setia.

Cruz, A. L. M., Cruz, F. J. M., \& Antonio, O. C. C. (2018). Assessing the Revenue Raising Capacity of the Local Government of Bongabon in the Philippines. Journal of Public Administration and Governance, 8(3): 99. https://doi.org/10. 5296/jpag.v8i3.13381.

FaladeObalade, T. A., \& Dubey, S. (2014). Managing Tourism as a source of Revenue and Foreign direct investment inflow in a developing Country: The Jordanian Experience. International Journal of Academic Research in Economics and Management Sciences, 3(3), 15-42. https://doi.org/10.6007/IJAREMS/v3-i3/901.

Githinji, R. K., Mwaniki, M., Kirwa, K. J., \& Mutongwa, S. M. (2014). Information and Communication Technology (ICT) on Revenue Collection by Kenyan Counties. International Journal of Academic Research in Business and Social Sciences, 4(11), 238-260. https://doi.org/10.6007/IJARBSS/v4-i11/1303.

Karimi, H., Maina, K. E., \& Kinyua, J. M. (2017). Effect of Technology and Information Systems on Revenue Collection by the County Government of Embu, Kenya. International Academic Journal of Information Systems and Technology, 2(1), 19-35. Retrieved from http://www.iajournals.org/articles/iajist_v2_i1_19_ 35.pdf\%0ACitation.

Kementerian Dalam Negeri RI (2017). Surat Edaran Mendagri No. 910/106/SJ tentang Petunjuk Teknis Penganggaran, Pelaksanaan, dan Penatausahaan serta Pertanggungjawaban Dana BOS Satuan Pendidikan Negeri yang Diselenggarakan oleh Kabupaten/Kota.

Kementerian Dalam Negeri RI (2018). Peraturan Menteri Dalam Negeri Republik Indonesia Nomor 33 Tahun 2019 Tentang Pedoman Penyusunan Anggaran Pendapatan Daerah Tahun Anggaran 2020, Pub. L. No. 134 (2018). Indonesia. Retrieved from www.peraturan.go.id.

Lembaga Administrasi Negara. (2008). Teknik-teknik Analisis Manajemen. Jakarta: Lembaga Administrasi Negara (LAN) RI.

Mardiasmo. (2002). Otonomi \& Manajemen Keuangan Daerah. Edisi Kesatu. Yogyakarta: Andi Offset.

Mohamed, A. A. (2017). Challenges of Mogadishu Local Government Revenue. In Proceedings of the 2017 2nd International Conference on Humanities and Social Science (HSS 2017) (Vol. 83, pp. 529-533). Paris, France: Atlantis Press. https://doi.org/10.2991/hss-17.2017.92. 
Olatunji, O. C., \& Ayodele, K. B. (2017). Impact of ICT on Tax Administration in Nigeria. Glopbal Journal of Management and Business Research, 17(2), 24-33. Retrieved from https://globaljournals.org/GJMBR_Volume17/4-Impact-of-Information-Technology.pdf.

Otieno, O. C., Oginda, M., Obura, J. M., Aila, F. O., Ojera, P. B., \& Siringi, E. M. (2013). Effect of Information Systems on Revenue Collection by Local Authorities in Homa Bay County, Kenya. Universal Journal of Accounting and Finance, 1(1), 29-33. https://doi.org/10.13189/ujaf.2013.010104.

Pemerintah Kabupaten Gunungkidul (2017a). Peraturan Daerah Kabupaten Gunungkidul No. 6 Tahun 2017 tentang Pajak Daerah.

Pemerintah Kabupaten Gunungkidul. (2017b). Perubahan Rencana Pembangunan Jangka Menengah Daerah Tahun 2016-2021. Gunungkidul: Pemerintah Kabupaten Gunungkidul.

Putra, W. (2018). Tata Kelola Ekonomi Keuangan Daerah (Edisi 1, C). Depok: Rajawali Pers.

Sitompul, A., Syahnur, S., \& Ichsan, C. (2014). The Role of Hotel and Restaurant Taxes and Its Effect on Banda Aceh's Local Own Source Revenue. Aceh International Journal of Social Sciences, 3(1), 45-57.

Sugiyono. (2016). Memahami Penelitian Kualitatif. Bandung: CV Alfabeta.

Tangkilisan, H. N. S. (2007). Manajemen Publik. Eds. Y. Hardiwati, Edisi Kedua. Jakarta: PT Grasindo.

Ylvije, B.-K., \& Elez, O. (2012). Management of the taxation on tourism operators, an important component of revenues and investments in the tourism sector. Academicus International Scientific Journal, 6, 126-135. https://doi.org/10.7336/ academicus.2012.06.12. 